\title{
Хірургічне лікуваннях хворих із місцеворозповсюдженими пухлинами підшлункової залози
}

\begin{abstract}
Мета роботи: оцінити результати виконання розширених резекцій підшлункової залози у лікуванні хворих з місцеворозповсюдженою аденокарциномою підшлункової залози.

Матеріали і методи. За період 2010-2018 рр. виконано 618 радикальних резекцій підшлункової залози у пацієнтів з аденокар-

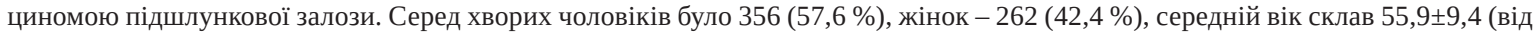
27 до 87 років). Дистальну резекцію підшлункової залози виконано у 139 (22,5 \%) хворих, панкреатодуоденальну резекцію - у 462 (74,8 \%), тотальну панкреатектомія - у 17 (2,7 \%) хворих. Розширені резекції підшлункової залози виконано у 142 (23,0 \%) хворих: розширені панкреатодуоденальні резекції - у 79 (55,6 \%), розширені дистальні резекції - у 52 (36,6 \%), розширені панкреатектомії - у 11 (7,8 \%). Розширені резекції підшлункової залози з резекцією венозних судин виконано у 91 (14,7 \%) хворого, з резекцією артерій - у 14 (2,3 \%) хворих.

Результати досліджень та їх обговорення. Ускладнення спостерігались у 182 пацієнтів (38,2 \%) при стандартних резекціях та у $63(44,3 \%)$ хворих у групі з розширеними резекціями $\left(x^{2}=1,26\right.$ p=0,26), достовірної різниці не було. Летальність склала 2,4 \%, померло 15 пацієнтів: 6 (4,2 \%) - після розширених резекцій та 9 (1,9 \%) - після стандартних резекцій підшлункової залози достовірної різниці в рівні летальності не було $\left(\mathrm{x}^{2}=1,3, \mathrm{p}=0,25\right)$. Медіана виживаності та 5-річна загальна виживаність були недостовірно нижче у пацієнтів після розширених панкреатодуоденальних резекцій, ніж після стандартних (15 місяців і $18 \%$ та 25 місяців і $27 \%$ відповідно ( $\left.x^{2}=2,83, p=0,09, p>0,05, x^{2}=0,16, p=0,69\right)$ ). Медіана виживаності була також недостовірно нижче у пацієнтів після розширених дистальних резекцій П3, ніж після стандартних (30 місяців та 32 місяці, відповідно, $\left.\mathrm{X}^{2}=0,008, \mathrm{p}=0,9, \mathrm{p}>0,05\right)$. Летальність, рівень післяопераційних ускладнень, віддалені результати лікування після розширених резекцій ПЗ зіставні із стандартними резекціями. Розширені резекції є можливими, і їх виконання може збільшити кількість радикально прооперованих хворих.
\end{abstract}

Ключові слова: розширені резекції підшлункової залози; аденокарцинома підшлункової залози; місцеворозповсюджені пухлини; венозні резекції; судинні реконструкції; артеріальні резекції.

Постановка проблеми і аналіз останніх досліджень та публікацій. Незважаючи на покращення рівня діагностики та лікування, протокова аденокарцинома підшлункової залози (ПЗ) залишається на четвертому місці серед причин смерті, пов’язаної з раком у Европі та США з 5-річною виживаністю в високоспеціалізованих центрах від 7 до 25 \% [1, 2]. В найближчому майбутньому протокова аденокарцинома ПЗ може стати на друге місце через причину смерті, пов'язану з раком у світі.

Більш ніж 78000 нових випадків зареєстровано в Європі в 2012 р. В Україні, згідно з даними Національного канцер-реестру, кількість хворих із роками останнім часом збільшується: в 2014 році діагностовано 4303 нових випадки, померло 3474 чоловіка, в 2017 році діагностовано 4380 нових випадків, померло 3457 чоловік [3].

На жаль, лише від 10 до 30 \% усіх пацієнтів 3 аденокарциномою ПЗ мають локальну пухлину та піддаються хірургічній резекції на момент діагностики. Близько 60 \% пацієнтів госпіталізовують із розповсюдженим процесом та наявністю метастазів [4, 5]. У зв’язку з локорегіонарним зростанням та раннім системним розповсюджен- ням аденокарциноми ПЗ локальна інвазія магістральних судин та прилеглих органів, наявність віддалених метастазів часто обмежують резектабельність пухлини $[6,7]$. Таким чином, комбіноване лікування з розширеними резекціями ПЗ нерідко є єдиною можливістю на їх радикальне лікування та довготривале виживання [8-12].

Попередні дані літератури не показали збільшення кількості ускладнень та летальності при виконанні розширених резекцій ПЗ, однак ризик виконання цих оперативних втручань високий. Потребує подальшого вивчення проблема ефективності розширених резекцій підшлункової залози при місцеворозповсюджених пухлинах та доцільність їх виконання.

Отже, сучасний стан проблеми виконання розширених резекцій у хворих з пухлинами підшлункової залози та періампулярної зони визначає актуальність і доцільність її поглибленого вивчення.

Мета роботи: оцінити результати виконання розширених резекцій підшлункової залози у лікуванні хворих із місцеворозповсюдженою аденокарциномою підшлункової залози. 
Матеріали і методи. За період з 2010 по 2018 рік ми виконали 618 радикальних резекційних втручань на ПЗ у пацієнтів з аденокарциномою П3. Серед хворих чоловіків було 356 (57,6 \%), жі-

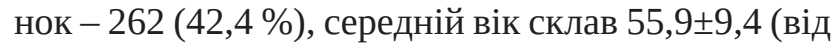
27 до 87 років). Дистальну резекцію підшлункової залози виконані у 139 (22,5 \%) хворих, панкреатодуоденальну резекція (ПДР) - у 462 (74,8 \%), тотальна панкреатектомія - у 17 (2,7 \%) хворих.

Всім пацієнтам було проведено планове доопераційне обстеження. За даними доопераційних методів обстеження оцінено резектабельність первинної пухлини. Діагноз був підтверджений даними морфологічного дослідження матеріалу.

Розширені резекції підшлункової залози виконано у 142 (23,0 \%) хворих: панкреатодуоденальні резекції - у 79 (55,6 \%), дистальні резекції - у 52 (36,6 \%), панкреатектомії - у 11 (7,8 \%). Розширені резекції підшлункової залози з резекцією венозних судин виконані у 91 (14,7 \%) хворого, з резекцією артерій - у 14 (2,3 \%) хворих.

Розширені панкреатодуоденектомії з артеріальними резекціями були виконані у 5 пацієнтів, з венозними резекціями - у 57 із них 2 з резекцією нижньої порожнистої вени. У 1 пацієнта виконана ПДР із циркулярною резекцією лівої печінкової артерії, у 2 пацієнтів виконана ПДР із резекцією правої печінкової артерії, у 2 - $з$ резекцією загальної печінкової артерії. У всіх випадках виконано артеріальний анастомоз “кінець-в-кінець”.

ПДР із резекцією брижі товстої кишки виконана у 7 пацієнтів, з резекцією тонкого кишечника у 1, з резекцією товстого кишечника - у 2, з резекцією лівого наднирника - у 1 пацієнта. У 4 хворих

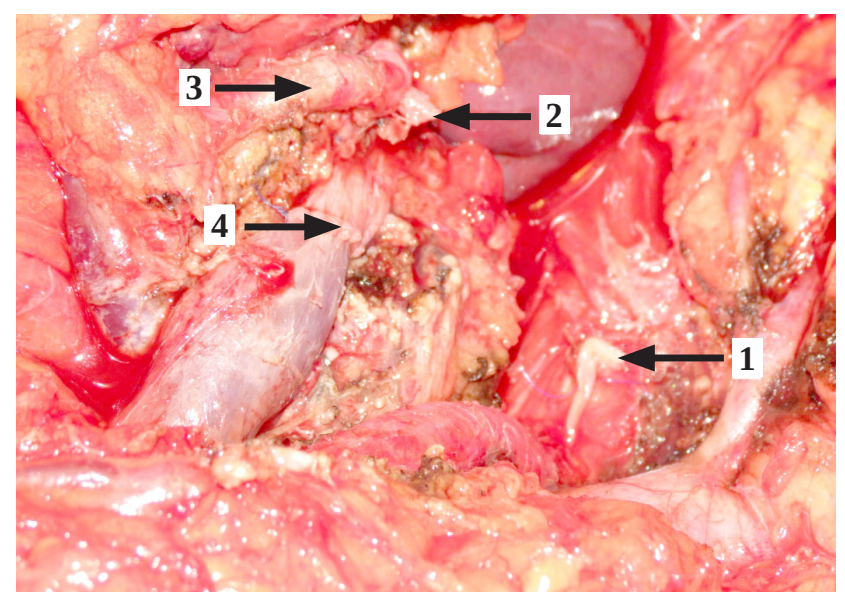

Рис. 1. Інтраопераційне зображення. Виконано модифіковану операцію Appleby з резекцією портоспленомезентеріального конфлюєнса та венозним анастомозом кінець-в-кінець (1 - кукса черевного стовбура, 2 - кукса загальної печінкової артерії, 3 - гастродуоденальна артерія, 4 - венозний анастомоз). виконано ПДР із комбінованою резекцією уражених органів: у 3 хворих ПДР була доповнена резекцією ворітної вени та брижі ободової кишки, у 1 пацієнта було виконано резекцію брижі товстого кишечника, крайову резекцію верхньої брижової вени (ВБВ) та атипову резекцію печінки.

Розширені дистальні резекції підшлункової залози виконано у 52 (36,6 \%) хворих. Розширені дистальні резекції ПЗ із резекціями артеріальних судин виконані у 8 хворих: у 5 хворих це була модифікована операція Appleby, а у 3 хворих були виконані комбіновані резекції (артеріальні резекції з додатковою резекцією уражених органів). У 1 хворого виконано дистальну резекцію підшлункової залози (RAMPS posterior) з резекцією лівої шлункової артерії та резекцією лівої ніжки діафрагми, у 1 хворого виконано дистальну субтотальну резекцію підшлункової залози з резекцією портоспленомезентеріального конфлюєнса, брижі ободової кишки та з резекцією загальної печінкової артерії, у 1 хворого виконано дистальну резекцію ПЗ з резекцією брижі товстого кишечника та 3 резекцією загальної печінкової артерії.

Розширені дистальні резекції ПЗ із резекціями венозних судин виконані у 25 хворих, із них у 1 хворої виконано дистальну субтотальну резекцію ПЗ зі спленектомією, з резекцією портоспленомезентеріального конфлюєнса 3 аутовенозним протезуванням графтом з лівої ниркової вени (рис. 2), а у 1 хворого дистальну резекцію з резекцією лівої шлункової вени.

У 21 хворого виконані розширені дистальні резекції підшлункової залози з комбінованою резекцією уражених органів.

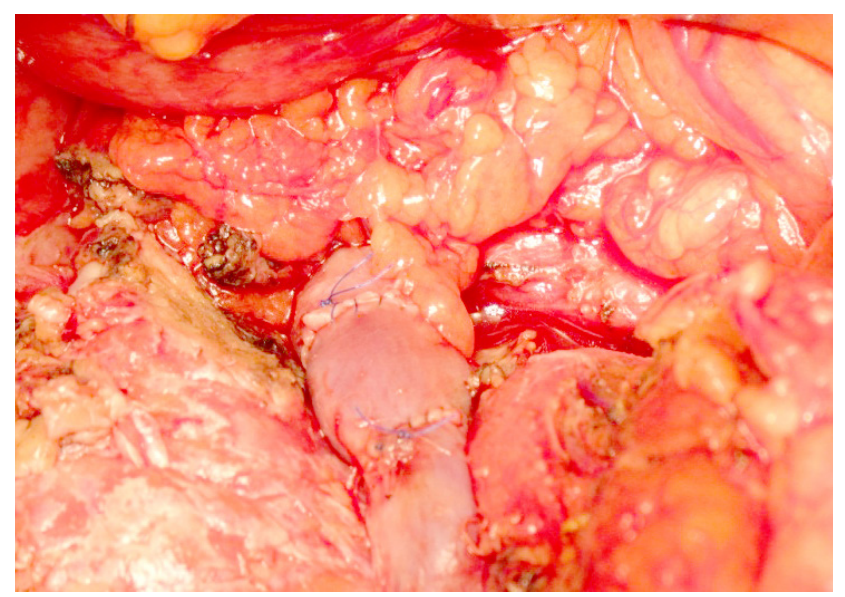

Рис. 2. Інтраопераційне фото. Виконано дистальну резекцію підшлункової залози з циркулярною резекцією портоспленомезентеріального конфлюєнса 3 наступним формуванням анастомозу кінець-в-кінець 3 ауто-венозним графтом із лівої ниркової вени. 
Розширені тотальні панкреатектомії виконано в 11 (7,8 \%) хворих. Розширену тотальну панкреатектомію з комбінованою артеріально-венозною резекцією виконано у 1 хворого: пацієнту виконано резекцію портоспленомезентеріального конфлюєнса з резекцією та пластикою правої печінкової артерії, яка відходила окремим стовбуром від верхньої брижової артерії (ВБА). Розширена тотальна панкреатектомія з лише венозними резекціями виконана у 9 пацієнтів. У 1 з них виконана резекція портоспленомезентеріального конфлюєнса та резекція нижньої порожнистої вени. У 1 пацієнта виконано тотальну панкреатектомія з нефректомією.

Всього виконано 91 венозну резекцію. Крайова резекція ворітної вени, верхньої брижової вени або портоспленомезентеріального конфлюєнса виконано у 53 хворих (Туре 1), згідно з класифікацією варіантів резекцій портоспленомезентеріального конфлюєнса за даними ISGPS, циркулярну венозну резекцію з венозним анастомозом кінецьв-кінець (Туре 3) виконано у 31 хворого. Відновлення венозного кровотоку з використанням аутовенозного графту виконано у 3 хворих, у 1 хворого використано синтетичний судинний протез (Туре 4). У 3 хворих виконано крайову резекцію вени з застосуванням латки з аутовени (Туре 2). Виконані артеріальні резекції були описані вище.

Ускладнення були розподілені згідно з даними рекомендацій міжнародної дослідницької групи хірургії підшлункової залози (ISGPS). Летальністю вважали смерть хворих протягом 90 діб після оперативного втручання.

Серед специфічних хірургічних ускладнень виділяли: панкреатичну норицю, згідно 3 новим переглядом міжнародної дослідницької групи із панкреатичної нориці (The 2016 update of the International Study Group definition and grading of postoperative pancreatic fistula: 11 years after), кровотечу, гастростаз, нагноєння післяопераційної рани, післяопераційний панкреатит, інтраабдомінальне скупчення рідини біля анастомозів, інтраабдомінальний абсцес, перитоніт.

Критеріями порівняння методик стандартних та розширених оперативних втручань були: кількість ускладнень, тривалість оперативного втручання (хв), крововтрата (мл), тривалість стаціонарного лікування, летальність, медіана виживаності, 5-річна виживаність.

Отримані дані комп’ютеризовані та зведені в загальну базу даних.

Для уточнення потенційних факторів ризику виникнення післяопераційних ускладнень застосовували методи математичної обробки да- них. Наявність зв'язку між зазначеними факторами і частотою ускладнень вивчали за допомогою аналізу таблиць часток і пропорцій з застосуванням критерію відповідності хі-квадрат. 3 метою 3'ясування тісноти взаємозв'язку між показниками двох виборок визначали коефіцієнт рангової кореляції Спірмена р. Вірогідність відмінності середніх величин оцінювали за допомогою критерію Манна-Уїтні. Для оцінки віддалених результатів лікування користувались показниками актуаріального 5-річного виживання, які обчислювали за допомогою процедури Каплана-Майера. Всі розрахунки проводились за допомогою пакетів прикладного програмного забезпечення MS Excel та Statistica 5,0.

Результати досліджень та їх обговорення. Післяопераційні специфічні ускладнення виникли у 182 (38,2 \%) хворих у групі стандартних резекцій і у 63 (44,3 \%) - в групі пацієнтів, яким були виконані розширені резекції підшлункової залози, різниця була недостовірна $\left(x^{2}=1,26, p=0,26\right)$. Померло 15 (2,4 \%) пацієнтів: 6 (4,2 \%) - після розширених резекцій підшлункової залози та 9 (1,9 \%) після стандартних резекцій. Летальність була недостовірно вище в групі хворих із розширеними резекціями підшлункової залози $\left(\mathrm{x}^{2}=2,5, \mathrm{p}=0,11\right)$.

У пацієнтів із венозними резекціями ускладнення виникли у 43 (47,2 \%) хворих, що було недостовірно вище порівняно зі стандартними резекціями, де ускладнення виникли у 182 (38,2 \%) хворих, $\left(X^{2}=2,1, p=0,14\right)$. В групі хворих із венозними резекціями померло 4 хворих, що склало 4,4 \%. Летальність в групі хворих із венозними резекціями була недостовірно вища $\left(\mathrm{X}^{2}=2,1, \mathrm{p}=0,14\right)$ порівняно $з$ летальністю при стандартних резекція, де летальність склала 9 (1,9 \%). Отже, достовірної різниці в кількості ускладнень та летальності не було.

Летальність у групі хворих з артеріальними резекціями склала 2 випадки (18,2 \%), що було достовірно вище $\left(\chi^{2}=12,9, p=0,0003\right)$, ніж в групі хворих, яким були виконані стандартні резекції.

Достовірної різниці в рівні ускладнень та летальності між розширеними резекціями ПЗ із резекцією суміжних органів порівняно зі стандартними резекціями не було.

Найбільш клінічно значимими ми вважаємо такі ускладнення, як панкреатична нориця, кровотеча, гастростаз. Панкреатичні нориці після розширених резекцій виникли у 22 (15,5 \%) хворих та у 65 (13,6 \%) хворих після стандартних резекцій, різниця була недостовірною $\left(\mathrm{x}^{2}=0,58, \mathrm{p}=0,3\right)$. Постпанкреатрезекційна кровотеча виникла - у 33 хво- 
рих із них у 20 (14 \%) хворих після розширених резекцій та у 13 (2,7 \%) після стандартних резекцій, різниця була достовірною $\left(\mathrm{x}^{2}=27,2, \mathrm{p}=0,0001\right)$. Гастростаз виник у 11 (7,7 \%) хворих після розширених резекцій підшлункової залози та у 12 $(2,5 \%)$ хворих після стандартних резекцій $\left(\mathrm{x}^{2}=8,3\right.$, $\mathrm{p}=0,003)$, різниця, також, була достовірною.
Для порівняння методик стандартних та розширених оперативних втручань були вивчені періопераційні та післяопераційні результати у 545 хворих, а саме: тривалість оперативного втручання (хв), крововтрата (мл), кількість ускладнень, тривалість стаціонарного лікування. Отримані дані наведено в таблиці 1.

Таблиця 1. Періопераційні та післяопераційні результати стандартних та розширених резекцій підшлункової залози

\begin{tabular}{|c|c|c|c|c|c|c|}
\hline \multirow[b]{2}{*}{ Показник } & \multicolumn{2}{|c|}{ ПДР } & \multicolumn{2}{|c|}{ ДР } & \multicolumn{2}{|c|}{ ТПЕ } \\
\hline & $\begin{array}{c}\text { стандартні } \\
\text { резекції } \\
\text { n = 415 }\end{array}$ & $\begin{array}{c}\text { розширені } \\
\text { резекції } \\
\text { n = } 79\end{array}$ & $\begin{array}{c}\text { стандартні } \\
\text { резекції } \\
\text { n = 53 }\end{array}$ & $\begin{array}{c}\text { розширені } \\
\text { резекції } \\
\text { n = } 52\end{array}$ & $\begin{array}{c}\text { стандартні } \\
\text { резекції } \\
\text { n = } 8\end{array}$ & $\begin{array}{c}\text { розширені } \\
\text { резекції } \\
\text { n = } 11\end{array}$ \\
\hline $\begin{array}{l}\text { Середня тривалість } \\
\text { операції, хв }\end{array}$ & $351,1 \pm 83,7$ & $\begin{array}{c}350,3 \pm 84,6 \\
U=6515 \\
p=0,03\end{array}$ & $250,4 \pm 71,2$ & $\begin{array}{c}289,8 \pm 74,8 \\
U=599,0 \\
p=0,005\end{array}$ & $360,6 \pm 78,3$ & $\begin{array}{c}395,8 \pm 55,9 \\
U=19 \\
p=0,56\end{array}$ \\
\hline $\begin{array}{l}\text { Середня крововтрата, } \\
\text { мл }\end{array}$ & $419,7 \pm 228,9$ & $\begin{array}{c}626,7 \pm 555,5 \\
U=6462 \\
p=0,1\end{array}$ & $512,5 \pm 332,8$ & $\begin{array}{c}610,29 \pm 330,2 \\
U=1617 \\
p=0,32\end{array}$ & $649,4 \pm 460,4$ & $\begin{array}{c}950 \pm 459,3 \\
U=15, \\
p=0,26\end{array}$ \\
\hline $\begin{array}{l}\text { Частота ускладнень, } \\
\text { n, \% }\end{array}$ & $152(45,2 \%)$ & $\begin{array}{c}28(43 \%) \\
\left(x^{2}=2,63\right. \\
p=0,1)\end{array}$ & $19(23,4 \%)$ & $\begin{array}{c}17(36,9 \%) \\
\left(x^{2}=2,63\right. \\
p=0,1)\end{array}$ & $1(16,7 \%)$ & $\begin{array}{l}5(50 \%) \\
\left(\chi^{2}=1,77\right. \\
p=0,18)\end{array}$ \\
\hline $\begin{array}{l}\text { Середня тривалість } \\
\text { лікування хворого у } \\
\text { стаціонарі, днів }\end{array}$ & $18,7 \pm 13,3$ & $\begin{array}{c}19,9 \pm 20,7 \\
U=8660 \\
p=0,87\end{array}$ & $13,6 \pm 6,85$ & $\begin{array}{c}20,5 \pm 14,4 \\
U=755,0 \\
p=0,25\end{array}$ & $16 \pm 5,34$ & $\begin{array}{l}12 \pm 7,4 \\
U=16,5 \\
p=0,19\end{array}$ \\
\hline
\end{tabular}

Медіана виживаності у хворих, яким виконано розширені резекції ПЗ порівняно з пацієнтами після виконання стандартних резекцій, склала 21 місяць та 28 місяців відповідно $\left(\mathrm{x}^{2}=0,16, \mathrm{p}=0,69\right.$, $\mathrm{p}>0,05)$.

5-річна виживаність після розширених резекцій підшлункової залози з приводу аденокарциноми головки склала 26 \%, після стандартних резекцій $29 \%\left(x^{2}=0,16, p=0,69, p>0,05\right)$ (рис. 3).

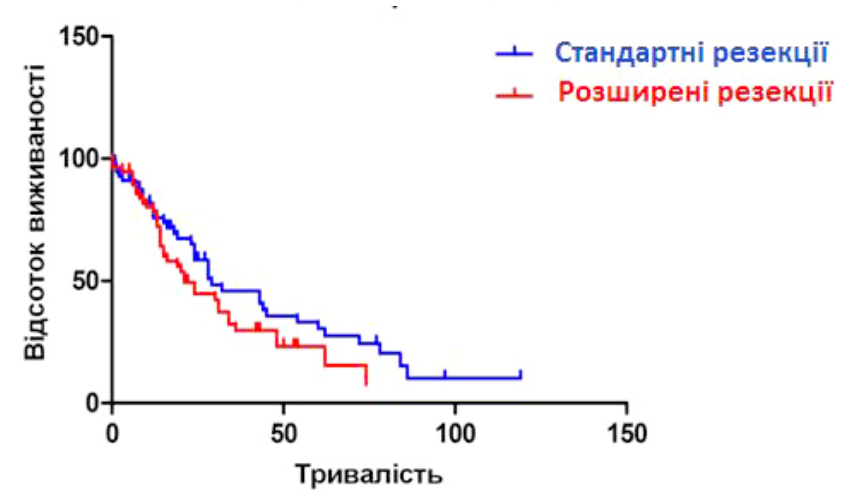

Рис. 3. Виживаність: криві виживаності.
За даними ряду авторів розширені резекції підшлункової залози асоціювалися з більшою тривалістю оперативного втручання, більшою крововтратою та більшою кількістю післяопераційних ускладнень [1, 5].

За нашими даними, тривалість оперативного втручання була достовірно меншою при стандартних ПДР та при стандартних дистальних резекціях порівняно з розширеними. Достовірної різниці в рівні крововтрати не було.

За даними ретроспективного аналізу виконання розширених резекцій, ПЗ Buchler M. W та співавтори [1] показали, що розширені резекції ПЗ асоціюються зі значно більшою кількістю ускладнень та летальністю порівняно зі стандартними методиками.

За нашими даними, достовірної різниці в рівні ускладнень після стандартних та розширених резекцій не було.

Результати багатьох досліджень демонструють відсутність різниці в довготривалій виживаності для пацієнтів із венозною або без венозної резекції, в рівні післяопераційних ускладнень та летальності [1-5]. Ми отримали подібні результа- 
ти. Летальність в групі хворих із венозними резекціями була недостовірно вища порівняно з летальністю при стандартних резекціях. Резекція уражених магістральних венозних судин достовірно не впливала на кількість післяопераційних ускладнень та тривалість життя хворих в порівнянні зі стандартними резекціями.

Необхідність виконання артеріальних резекцій $є$ суперечливою на теперішній час, так як вони асоціюються з високим ризиком виникнення післяопераційних ускладнень та високою летальністю, але багато авторів показують значні переваги в виживаності хворих в порівнянні з паліативними оперативними втручаннями при яких медіана виживаності складає 6-8 місяців [1-7]. За нашими даними, летальність в групі хворих з артеріальними резекціями склала 18,2 \%, що було достовірно вище $\left(x^{2}=12,9, p=0,0003\right)$, ніж в групі хворих, яким були виконані стандартні резекції.

Стосовно виживаності, то після двох панкреатодуоденальних резекцій з резекцією правої печінкової артерії хворі прожили 18 місяців та 31 місяць, а після резекції загальної печінкової артерії хворі померли в період від 1 до 3 років. За нашими даними, після дистальної резекції (RAMPS posterior з резекцією лівої шлункової артерії та лівої ніжки діафрагми) хворий прожив 12 місяців без ознак рецидиву; а після модифікованої операції Appleby (дистальна субтотальна резекція підшлункової залози з резекцією черевного стовбуру) 3 резекцією портоспленомезентеріального конфлюенсу та анастомозом “кінець-в-кінець”

\section{СПИСОК ЛІТЕРАТУРИ}

1. Kaiser J. Extended pancreatectomy: Does it have a role in the contemporary management of pancreatic adenocarcinoma? / J. Kaiser, T. Hackert, M. W. Buchler // Dig. Surg. - 2017. DOI: $10.1159 / 000478539$

2. Reassessment of the clinical significance of portal superior mesenteric vein invasion in borderline resectable pancreatic cancer / S. Hoshimoto, S. Hishinuma, H. Shirakawa [et al.] // Eur. J. Surg. Oncol. - 2017. - Access mode : http://dx.doi. org/10.1016/j.ejso.2017.03.020

3. Рак в Україні, 2016-2017 / 3. П. Федоренко, Л. О. Гулак, Ю. Й. Михайлович [та ін.] // Бюлетень Національного канцер-реєстру. - № 19. - С. 32-34.

4. Outcomes after extended pancreatectomy in patients with borderline resectable and locally advanced pancreatic cancer / W. Hartwig, A. Gluth, U. Hinz [et al.] // Br. J. Surg. - 2016. Vol. 103 (12). - P. 1683-1694. DOI: 10.1002/bjs.10221

5. Perioperative treatment options in resectable pancreatic cancer - how to improve long-term survival / M. Sinn, M. Bahra, T. Denecke [et al.] // World J. of Gastrointest. Oncol. - 2016. Vol. 8, No. 3. - P. 248-257. DOI: 10.4251/wjgo.v8.i3.248

6. Kasumova G. G. The role of venous and arterial resection in pancreatic cancer surgery / G. G. Kasumova, W. C. Conway, хворий прожив без ознак рецидиву 14 місяців. Після модифікованої операції Appleby (дистальна субтотальна резекція підшлункової залози з резекцією черевного стовбуру) 4 хворих пережили 1 рік після оперативного втручання.

За нашими даними медіана виживаності була недостовірно менше у пацієнтів, яким були виконані розширені дистальні резекції ПЗ в порівнянні з пацієнтами після виконання стандартних дистальних резекцій ПЗ у пацієнтів з аденокарциномою тіла та хвоста ПЗ (30 місяців та 32 місяці відповідно, $\left.\chi^{2}=0,008, p=0,9, p>0,05\right)$. Стосовно панкреатодуоденальних резекцій ПЗ, то медіана виживаності після розширених ПДР була 15 місяців, після стандартних ПДР - 25 місяців, достовірної різниці не було $\left(\mathrm{x}^{2}=2,83, \mathrm{p}=0,09, \mathrm{p}>0,05\right)$, 5-річна виживаність після розширених резекцій підшлункової залози з приводу аденокарциноми головки склала $18 \%$, після стандартних резекцій $27 \%\left(x^{2}=0,16, p=0,69, p>0,05\right)$. За даними світової літератури, в провідних центрах надають подібні результати [8-12].

Висновки. 1. Летальність, рівень післяопераційних ускладнень, віддалені результати лікування після розширених резекцій ПЗ зіставні зі стандартними резекціями.

Розширені резекції є можливими. Виконання розширених резекцій підшлункової залози забезпечує збільшення загальної кількості радикальних оперативних втручань без достовірного збільшення кількості ускладнень та летальності.

J. F. Tseng // Ann. Surg. Oncol. - 2016. - Vol. 23. - P. 1-8. DOI: 10.1245/s10434-016-5676-3

7. Extended pancreatectomy in pancreatic ductal adenocarcinoma: definition and consensus of the International Study Group for Pancreatic Surgery (ISGPS) / W. Hartwig, C. M. Vollmer, A. Fingerhut [et al.] // Surgery. - 2014. - Vol. 156. - P. 1-14. DOI: 10.1016/i.surg.2014.02.009

8. Management of borderline and locally advanced pancreatic cancer: where do we stand? / J. He, A. J. Page, M. Weiss [et al.] // World J. Gastroenterol. - 2014. - Vol. 20. - P. 2255-2266. DOI: 10.3748/wjg.v20.i9.2255

9. Outcome of superior mesenteric-portal vein resection during pancreatectomy for borderline ductal adenocarcinoma: results of a prospective comparative study / F. Selvaggi, G. Mascetta, D. Daskalaki [et al.] // Langenbeck's Arch. Surg. - 2014. Vol. 399. - P. 659-665. DOI:10.1007/s00423-014-1194-6

10. Is pancreatic head cancer with portal venous involvement really borderline resectable? Appraisal of an upfront surgery series / K. Ohgi, Y. Yamamoto, T. Sugiura, [et al.] // Ann. Surg. Oncol. - 2017. - Vol. 24 (9). - P. 2752-2761. DOI:10.1245/ s10434-017-5972-6

11. International Association of Pancreatology (IAP)/European 


\section{З ДОСВІДУ РОБОТИ}

Pancreatic Club (EPC) consensus review of guidelines for the treatment of pancreatic cancer / K. Takaori, C. Bassi, A. Biankin [et al.] // Pancreatology. - 2016. - Vol. 16. - P. 14-27. DOI:10.1016/j.pan.2015.10.013
12. Cancer of the pancreas: ESMO Clinical Practice Guidelines for diagnosis, treatment and follow-up / M. Ducreux, A. Cuhna, C. Caramella [et al.] // Ann. of Oncol. - 2015. - Vol. 26 (Suppl. 5). - P. 56-68. DOI:10.1093/annonc/mdv295

\section{REFERENCES}

1. Kaiser, J., Hackert, T., \& Buchler, M.W. (2017). Extended pancreatectomy: Does it have a role in the contemporary management of pancreatic adenocarcinoma? Dig. Surg., 13. DOI: $10.1159 / 000478539$

2. Hoshimoto, S., Hishinuma, S., Shirakawa, H., Tomikawa, M., Ozawa, I., \& Wakamatsu, S. (2017). Reassessment of the clinical significance of portal superior mesenteric vein invasion in borderline resectable pancreatic cancer. Eur. J. Surg. Oncol. Retrieved from: http://dx.doi.org/10.1016/j.ejso.2017.03.020

3. Fedorenko, Z.P., Hulak, L.O., \& Mykhailovych, Yu.Y. Rak v Ukraini, 2016-2017 [Cancer in Ukraine 2016-2017]. Biuleten Natsionalnoho kantser-reiestru - Bulletin of the National CancerRegister, 19, 32-34 [in Ukrainian].

4. Hartwig, W., Gluth, A., Hinz, U., Koliogiannis, D., Strobel, O., \& Hackert, T. (2016). Outcomes after extended pancreatectomy in patients with borderline resectable and locally advanced pancreatic cancer. Br. J. Surg., 103 (12), 1683-1694. DOI: 10.1002/bjs.10221

5. Sinn, M., Bahra, M., Denecke, T., Travis, S., Pelzer, U., \& Riess, H. (2016). Perioperative treatment options in resectable pancreatic cancer - how to improve long-term survival. World J. of Gastrointest. Oncol., 8 (3), 248-257. DOI: 10.4251/wjgo.v8.i3.248 6. Kasumova, G.G., Conway, W.C., \& Tseng, J.F. (2016). The role of venous and arterial resection in pancreatic cancer surgery. Ann. Surg. Oncol., 23, 1-8. DOI: 10.1245/s10434-016-5676-3 7. Hartwig, W., Vollmer, C.M., Fingerhut, A., Yeo, C.J., Neoptolemos, J.P., \& Adham, M.(2014). Extended pancreatectomy in pancreatic ductal adenocarcinoma: definition and consensus of the International Study Group for Pancreatic Surgery (ISGPS). Surgery, 156, 1-14. DOI: 10.1016/i.surg.2014.02.009

8. He, J., Page, A.J., Weiss, M., Wolfgang, C.L., Herman, J.M., \& Pawlik, T.M. (2014). Management of borderline and locally advanced pancreatic cancer: where do we stand? World J. Gastroenterol., 20, 2255-2266. DOI: 10.3748/wjg.v20.i9.2255 9. Selvaggi, F., Mascetta, G., Daskalaki, D., Molin, M., Salvia, R., \& Butturini, G. (2014). Outcome of superior mesenteric-portal vein resection during pancreatectomy for borderline ductal adenocarcinoma: results of a prospective comparative study. Langenbeck's Arch. Surg., 399, 659-665. DOI:10.1007/s00423014-1194-6

10. Ohgi, K., Yamamoto, Y., Sugiura, T., Okamura, Y., Ito, T., \& Ashida, R. (2017). Is pancreatic head cancer with portal venous involvement really borderline resectable? Appraisal of an upfront surgery series. Ann. Surg. Oncol., (9), 2752-2761. DOI:10.1245/ s10434-017-5972-6

11. Takaori, K., Bassi, C., Biankin, A., Brunner, T., Cataldo, I., \& Campbell, I. (2016). International Association of Pancreatology (IAP)/European Pancreatic Club (EPC) consensus review of guidelines for the treatment of pancreatic cancer. Pancreatology, 16, 14-27. DOI:10.1016/j.pan.2015.10.013

12. Ducreux, M., Cuhna, A., Caramella, C., Hollebecque, A., Burtin, P., \& Goere, D. (2015). Cancer of the pancreas: ESMO Clinical Practice Guidelines for diagnosis, treatment and followup. Ann. of Oncol., 26 (5), 56-68. DOI:10.1093/annonc/mdv295

Отримано 21.10.2019

Електронна адреса для листування: perervalunet@bigmir.net

V. M. KOPCHAK, M. V. KOSTYLIEV, L. O. PERERVA, O. V. DUVALKO, V. V. KHANENKO, H. H. SHEVKOLENKO, S. V. ANDRONIK, V. I. TRACHUK

O. Shalimov National Institute of Surgery and Transplantology, National Academy of Medical Sciences of Ukraine, Kyiv

\section{SURGICAL TREATMENT OF PATIENTS WITH LOCALLY ADVANCED PANCREATIC CANCER}

The aim of the work: to evaluate the outcome of extended pancreatectomy in treatment of patients with locally advanced pancreatic cancer. Materials and Methods. In the period 2010-2018 we performed 618 resections in patients with pancreatic adenocarcinoma: distal pancreatectomy - in 139 (22.5\%), pancreaticoduodenectomy - in 462 (74.8\%) and total pancreatectomy - in 17 (2.7\%) patients. Among

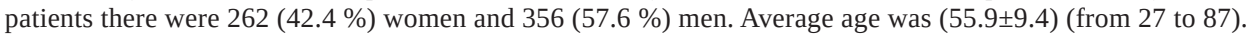

Extended pancreatectomy was performed in 142 (23.0\%) patients: extended pancreaticoduodenectomy - in 79 (55.6 \%), extended distal resections - in 52 (36.6 \%), extended pancreatectomy - in 11 (7.8 \%). Extended resections with resections of vein were performed in $91(14.7 \%)$ patients, with arterial resections - in 14 (2.3 \%) patients.

Results and Discussion. Postoperative complications occurred in 182 patients (38.2 \%) in the standard resection group and in 63 (44.3\%) in the group with extended resections $\left(x^{2}=1.26 \mathrm{p}=0.26\right)$, without significant difference. Mortality was $2.4 \%, 15$ patients died: $6(4.2 \%)$ after extended resections and $9(1.9 \%)$ - after standard pancreatectomy $\left(x^{2}=1.3, p=0.25\right)$. Median survival and 5-year overall survival rate were reduced in patients having extended pancreatectomy compared with those undergoing a standard resection (15 months, $18 \%$ and 25 months, $33 \% ; x^{2}=2.83, p=0.09, p>0,05, x^{2}=0.16, p=0,69$ ). The present results suggest that morbidity, mortality, long term results after $E P$ are comparable with standard pancreatectomy. Extended resections are possible and can increase the number of radically operated patients.

Key words: extended pancreatectomy; pancreatic adenocarcinoma; locally advanced pancreatic cancer; venous resections; vascular reconstruction; arterial resections. 
В. М. КОПЧАК, М. В. КОСТИЛЕВ, Л. А. ПЕРЕРВА, А. В. ДУВАЛКО, В. В. ХАНЕНКО, Г. Г. ШЕВКОЛЕНКО, С. В. АНДРОНИК, В. И. ТРАЧУК

гу “Национальный институт хирургии и трансплантологии имени А. А. Шалимова”, НАМН Украины, Киев

\section{ХИРУРГИЧЕСКОЕ ЛЕЧЕНИЕ БОЛЬНЫХ С МЕСТНОРАСПРОСТРАНЕННЫМИ ОПУХОЛЯМИ ПОДЖЕЛУДОЧНОЙ ЖЕЛЕЗЫ}

Цель работы: оценить результаты выполнения расширенных резекций поджелудочной железы в лечении больных с местнораспространенной аденокарциномой поджелудочной железы.

Материалы и методы. За период 2010-2018 гг. мы выполнили 618 радикальных резекций поджелудочной железы у пациентов с аденокарциномой поджелудочной железы. Среди больных мужчин было 356 (57,6 \%), женщин - 262 (42,4 \%), средний

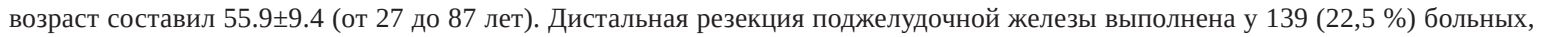
панкреатодуоденальная резекция - у 462 (74,8 \%), тотальная панкреатэктомия - у 17 (2,7 \%) больных. Расширенные резекции поджелудочной железы выполнены у 142 (23,0 \%) больных: расширенные панкреатодуоденальные резекции - у 79 (55,6 \%), расширенные дистальные резекции - у 52 (36,6 \%), расширенные панкреатэктомии - у 11 (7,8 \%). Расширенные резекции поджелудочной железы с резекцией венозних сосудов выполнены у 91 (14,7 \%) больного, с резекцией артерий - у 14 (2,3 \%) больных.

Результаты исследований и их обсуждение. Осложнения наблюдались у 182 (38,2 \%) больных при стандартных резекциях и у $63(44,3 \%)$ больных в группе с расширенными резекциями $\left(x^{2}=1,26\right.$ p=0,26), достоверной разницы не было. Летальность составила 2,4 \%, умерло 15 больных: 6 (4,2 \%) - после расширенных резекций и 9 (1,9 \%) - после стандартных резекций поджелудочной железы $\left(\mathrm{x}^{2}=1,3, \mathrm{p}=0,25\right)$. Медиана выживаемости и 5-летняя общая выживаемость были недостоверно ниже у пациентов после расширенных панкреатодуоденальных резекций, чем после стандартных (15 месяцев и 18 \% и 25 месяцев и $33 \%$, соответственно, $\left.\left.x^{2}=2,83, p=0,09, p>0,05, x^{2}=0,16, p=0,69\right)\right)$. Летальность, уровень послеоперационных ослонений, отдаленные результаты лечения после расширенных резекций поджелудочной железы сопоставимы со стандартными резекциями. Расширенные резекции являются возможными и их выполнение может увеличить количество радикально прооперированных больных.

Ключевые слова: расширенные резекции поджелудочной железы; аденокарцинома поджелудочной железы; местнораспространенные опухоли; венозные резекции, сосудистые реконструкции; артериальные резекции. 